\title{
Research instruments on environmental quality applied to small children with Down Syndrome
}

\author{
Instrumentos de pesquisa sobre qualidade especial \\ aplicados a crianças pequenas com Síndrome de Down
}

\begin{abstract}
Virginia Magliano Queiroz
Sheila Walbe Ornstein

Gleice Azambuja Elali

Abstract

hildren aged between 4 to 7 years play a minor role in academic studies in Architecture and Urbanism, a situation related to the difficulty of obtaining their opinions, especially those with intellectual disabilities, such as Children with Down Syndrome (CDS). Therefore, little is known about their perception of the built environment. For this to change, instruments should be developed in order to approach these children, which could contribute both to valuing their opinion and supporting the professional practice of architects. This finding led to exploratory, qualitative and interdisciplinary research to create research tools directed to young CDS, and obtain their opinion about the built environment. The study was based on: (a) literature review; (b) expert panels, comprising 10 parents and 28 professionals. Based on this information, three research instruments were prepared: Spatial Qualification Chart, Illustrated Cards and Make-believe in a Three-Dimensional Physical Model. They are tested with eleven CDS. The results showed that: (i) the proposed instruments fit the task; (ii) some care can facilitate the work with this public; (iii) the participating children perceive and qualify the space - which justifies new research endeavors with CDS.
\end{abstract}

Keywords: Methodological instruments. Spatial quality. Children with intelectual disabilities. Down syndrome.

\section{Resumo}

Crianças com idade entre 4 e 7 anos pouco atuam como protagonistas em estudos acadêmicos em Arquitetura e Urbanismo, situação relacionada à dificuldade em ouvi-las, em especial aquelas com deficiência intelectual, como as crianças com Síndrome de Down (CSD). Logo, sua percepção acerca do ambiente construído é pouco conhecida. Para que isso se modifique, é necessário desenvolver instrumentos para abordagem dessas crianças, o que pode contribuir para valorizar sua opinião e para apoiar o exercício

${ }^{1}$ Virginia Magliano Queiroz ${ }^{1}$ Faculdade Pitágoras Guarapari - ES - Brasil

${ }^{2}$ Sheila Walbe Ornstein 2Universidade de São Paulo São Paulo - SP - Brasil

${ }^{3}$ Gleice Azambuja Elali ${ }^{3}$ Universidade Federal do Rio Grande do Norte Natal - RN - Brasil

Recebido em 27/05/19 Aceito em 08/07/20 profissional de arquitetos. Essa constatação gerou uma pesquisa de caráter exploratório, qualitativo e interdisciplinar, visando criar instrumentos de pesquisa direcionados a crianças CSD pequenas, e obter sua opinião sobre o ambiente construído. $O$ estudo baseou-se em: (a) revisão de literatura; (b) painéis de especialistas, abrangendo 10 pais e 28 profissionais. A partir das informações obtidas foram elaborados três instrumentos de pesquisa: Quadro de Qualificação Espacial, Cartões Ilustrados e Faz-de-conta em Modelo Físico Tridimensional. Estes instrumentos foram testados com onze CSD. Os resultados mostraram que: (i) os instrumentos propostos se adequam à tarefa; (ii) pequenos cuidados podem facilitar o trabalho com esse público; (iii) em geral as crianças participantes indicam perceber e qualificar o espaço - o que justifica novas pesquisas com CSD.

Palavras-chave: Instrumentos metodológicos. Qualidade especial. Crianças com deficiêcia intellectual. Síndrome de Down. 


\section{Introduction}

Taking into account a child's opinion is no simple task, especially in an "adultcentric" world (SANT'ANA, 2010). Consequently, even in investigations that focus on children's needs and aspirations, many researchers choose to consult their legal representatives (parents and others) or professionals who have direct contact with the children (such as teachers, physicians, or therapists). Thus, in general, "[...] the child appears as a subject on which research is done [...]" and not as a protagonist that contributes directly to its results (FRANCISCO; BITTENCOURT, 2014, p. 3).

Only over the last twenty years children have been taken as social actors by researchers (SOARES; SARMENTO; TOMÁS, 2005), especially after the emergence of participatory research methodologies (FARGAS-MALET et al., 2010). However, research conducted with children raises several legal difficulties, requiring additional ethics concerns. This situation is justified by two main understandings:

(a) our society tends to view a child as a person who is still at the beginning of development, thus not really able to understand what it means to accept participating in research (SIGAUD et al., 2009); and

(b) institutions try to protect the child from unnecessary invasions and aggressions (CONSELHO..., 2012; ABATE; ONO; ORNSTEIN, 2018).

Notwithstanding this discussion, researchers are now "[...] recognizing the importance of considering the child as a participant in their research [...]" (GAIVA, 2009, p. 136), understanding their point of view as a source of data to be explored in depth and with seriousness (BORGERS; LEEUW; HOX, 2000; GAIVA, 2009).

Since the 1970s, authors from all over the world such as Nucci and Turiel (1978), Altman and Wohlwill (1978) and Weinstein et al. (1987) have emphasized the need to listen to children and incorporate their voice into the research and planning of their spaces and activities, especially in the case of educational and home environments. More recently, among the studies that considered small children as protagonists, those conducted by Shutts, Banaji and Spelke (2010), De Giuli, Da Pos and De Carli (2012), Fabbri (2013), Vásquez et al. (2014), Shaw, Brady and Davey (2011) and Zamani (2017) can be mentioned - some of which are in the field of environmental comfort.

In Brazil, this research practice is not often found in architectural and urban design studies, despite the pioneering investigation of Lima (1989) - who worked with children in public schools in São Paulo- and some research conducted in the academic field. In this regard, generally, academic Brazilian works involve only small children whose development accompanies age-related expectations, such as Azevedo (2002), Elali (2002), Caixeta and Lukiantchuki (2009), Martins et al. (2011), Natalino and Ávila (2016), and Vásquez, Pereira and Kuhnen (2018).

Thus, Carneiro and Vilela (2006) point out that since there is the consent of those in charge, children under two years of age can be involved in research without realizing it (especially if they are involved in their daily activities), which avoids discomfort and changes in their routine. This understanding has been extended to children with intellectual disabilities, not only according to their age, but also the level of commitment observed, and the researcher needs to have previously requested authorization from the REC/CONEP ${ }^{1}$ system (FERNANDES, 2016). Whenever possible, however, it is critical for the researcher to explain the research and obtain the child's consent, even if the legal representatives have already agreed.

When children have some form of deficiency, especially intellectual, this task becomes even more complex in psychological and educational areas, although in these fields professionals are predisposed and prepared to deal directly with this population. Studies involving such users and the assessment of environmental qualities conducted by designers and planners are atypical, given that such professionals have not been trained to deal with the physical and psychological constraints that involve people in differentiated intellectual conditions.

In a search carried out in the Digital Bank of Theses and Dissertations of the IBICT $^{2}$, only two academic examples were found: Carvalho (2008) and Abate (2011). Based on their work, some of the gaps detected

${ }^{1}$ The REC/CONEP system comprises the National Commission for Research Ethics (CONEP) and the Research Ethics Committees (RECs), "composing a system that uses mechanisms, instruments of interrelation in a cooperative work that especially aims to the protection of research participants in Brazil, in a coordinated and decentralized manner through an accreditation process"(CNS, 2012, s/p).

${ }^{2}$ IBICT -Instituto Brasileiro de Informação em Ciência e Tecnologia (Brazilian Institute of Information in Science and Technology) (http://bdtd.ibict.br/).

198 Queiroz, V. M.; Ornstein, S. W.; Elali, G. A. 
indicate the need for a greater focus on intellectual disability. To that end, a study was carried out to develop and test methodological instruments that could be applied to architectural research with small children ${ }^{3}$ with intellectual disabilities, based on experiences with CDS. That is, it was an exploratory research, consistent with the nature of the academic activity carried out and with the originality of the investigated field. Its purpose was to propose an appropriate instrument for that reality (PIOVESAN; TEMPORINI, 1995) and to raise questions for new studies, without necessarily providing the proof of results, in the field of classical dialectic "hypothesis - thesis".

The focus was on pre-school children because we understood that schooling would facilitate the research process, which could restrict the results obtained, as they would be applicable only to schooled children (a condition that, unfortunately, does not yet correspond to the reality of this group in Brazil).

Based on the proposed instruments, our objective was to understand:

(a) Do the participant children perceive the space, looking at the objects and furniture that surround them?

(b) Do they qualify space? Do they prefer one environment over another?

(c) What would the characteristics be of a suitable space for them?

(d) What do they like in an environment? and

(e) What do they not like in an environment? What bothers them?

To present the work done, this article is structured as follows: brief research context, methodological route (which occupies most of the article as it is the main focus), the main results and discussion and final considerations.

\section{Brief research context}

The quality of the social and physical environment in which the person is inserted is a sum of the characteristics of the physical space and the behaviors and attitudes of the individuals who are there. It influences the situations that occur in that place, being able to indicate if there will be problems in dealing with it and the extent of these difficulties.

According to the World Health Organization (WHO), "disability is not an attribute of the person" but rather the context in which he is inserted, so that "[...] progress in improving social participation can be achieved by dealing with barriers that affect people with disabilities in daily life [...]" (ORGANIZAÇÃO..., 2012, p. 4). Also according to the document, "[...] more than one billion people around the world live with some form of disability [...]" (ORGANIZAÇÃO..., 2012, p. xi), which means approximately one in seven people, with an estimated 200 million experiencing considerable functional difficulties. In addition, it is estimated that the incidence of disability has increased, leading to even greater concerns for the coming years (ORGANIZAÇÃO..., 2012).

Additionally according to international definitions and classifications, which consider the cause, origin and main characteristics of deficiencies, in Brazil the official definition of deficiencies is contained in Decree No. 5.296 (BRASIL, 2004). Among them, we highlight an explicit reference to the intellectual difficulties, the focus of this text, understood as:

[...] significantly lower than average intellectual functioning, with manifestation before the age of eighteen, and limitations associated with two or more areas of adaptive skills, such as: communication, personal care, social skills, use of community resources, health and safety, academic, leisure and work skills (BRASIL, 2004).

Although many of the causes of intellectual disability remain unknown, the most common diagnosable genetic cause is Down Syndrome (DS) (LOTT, 2012). DS is associated with an abnormality in the chromosomal constitution, in this case the presence of an extra chromosome 21 in the person's karyotype, called Trisomy 21 (BRUNONI, 1999; KOZMA, 2007; PIMENTEL, 2012; SCHWARTZMAN, 1999). Since birth, infants with DS have similar physical characteristics (phenotype), appearance and functions delimited according to their genetic material (PUESCHEL; REILY, 2003). The most common features are "[...] low muscle tone, oblique palpebral fissures and small ears [...]" (KOZMA, 2007, p. 31), intellectual impairment

${ }^{3}$ The term "small children" is used in this article to refer to children aged four to seven years. 
between mild and moderate (MCCONNAUGHEY; QUINN, 2007), besides behavioral and pattern of development (VOIVODIC, 2013). They are also susceptible to medical problems at a higher frequency than in the general population, especially: congenital anomalies such as cataracts and heart disease; infections, compulsive disorders and visual disturbances; psychiatric disorders and Alzheimer's (PUESCHEL; REILY .., 2003).

\section{Care in studies involving children}

Currently, research conducted with children is of interest in several fields, in which special attention is crucial to define the methods and techniques used, particularly the more invasive instruments. In the case of interviews and questionnaires, for example, "[...] even the definition of the questions [...] and its order go back to the ethical concern, since such formulation can induce responses that may distort the final result of the work [...]" (ELALI, 2010, p. 12).

In addition to choosing how to approach children, another ethical issue is the relationship of power established between adults and children, and it is important to avoid behavior of domination and to favor the free expression of children. To do this, "[...] attractive conditions that stimulate their participation and minimize discomfort [...]" should be created (SIGAUD et al., 2009, p. 1344), as well as guarantee their safety, how to approach a child in a known place (preferably their own environment), in the presence of people they trust (people of reference) and clearly offering them the possibility of refusing to participate. Regarding research etiquette and protocol, these authors also indicate behaviors to be cultivated by researchers when working with children:

(a) introduce yourself clearly (name and reason for contact);

(b) explain the research, ensuring that the child understands the procedures and how he/she may feel, and ask the child to tell/repeat what he/she understood;

(c) be honest and transparent;

(d) adopt attitudes of empathy, authenticity and consistency;

(e) demonstrate acceptance and interest for the child;

(f) gradual and successive approach, perhaps using toys;

(g) define flexible planning that can accommodate unexpected demands regarding the premises, sequence or form of application;

(h) attention to the child's tiredness and discomfort, offering the possibility of interrupting their participation;

(i) make toys available, without impeding the child's play in case he/she does not want to participate in the research; and

(j) at the end of the procedure, express your gratitude and make room for new contacts.

In short, respect for children's interests and desires are fundamental both for developing the research, as well as appreciation and autonomy of the child as a person (SIGAUD et al., 2009).

\section{Systematic Literature Review (SLR)}

A Systematic Literature Review (SLR) was conducted to present the current state of research that considers the opinion of CDS, which took place according to the search entries indicated in Table 1. The database covered relevant journals (publications in Web of Science, Scopus, ScienceDirect and Scielo) from 2009 to 2019.

The first search with the term "small children with Down Syndrome" did not yield results in the selected databases; however, the search for "children with Down Syndrome" resulted in 3,295 articles. It then looked for conjugate searches, adding this term to each of the other keywords. In this new configuration, 292 articles were identified, 64 which were repeated (and therefore excluded), totaling 228 eligible articles to continue the selection process. The eligibility of the identified articles was determined after reading their abstracts, according to the criteria set out in the protocol (Table 2). When the abstract did not present the necessary information for inclusion or exclusion of the article, a search for keywords was performed in the full text of the article or a careful reading of the methodology used was carried out. 
Although 228 articles were found, the search was not considered successful because the articles were identified in the search that mentioned DS as an example or comparing it to some evidence found. None of the studies treated children as active interlocutors. Careful reading identified that the 228 articles selected should have also been excluded as they addressed:

(a) sleep disorders and related disorders (ESTELLER MORÉ, 2010; LIN et al., 2014;

KONSTANTINOPOULOU et al., 2016);

(b) Autistic Spectrum Disorder (ASD) (TEA) (BONIS; SAWIN, 2016; CARDON; AZUMA, 2012; CROWELL; KELUSKAR; GORECKI, 2019; DAI et al., 2018);

(c) intellectual disability in general (SANDERS; ERICKSON, 2018; EMERSON, 2010; COLLINS; STAPLES, 2017); and

(d) other syndromes (FERNÁNDEZ; PUENTE; FERRANDO, 2010; SANMANEECHAI et al., 2013; VAN DEN HEUVEL et al., 2018).

Table 1 - Criteria and entries for the Systematic Literature Review (SLR)

\begin{tabular}{|c|c|c|c|}
\hline & CRITERIA & ENTRIES & \\
\hline \multirow{4}{*}{ Keywords } & \multirow{4}{*}{$\begin{array}{l}\text { Research goal, } \\
\text { questions and } \\
\text { main terms found } \\
\text { in the first } \\
\text { literature review. }\end{array}$} & $\begin{array}{l}\text { Small children with Down syndrome; } \\
\text { Children with Down syndrome; }\end{array}$ & \\
\hline & & $\begin{array}{l}\text { Spatial quality; } \\
\text { Spatial perception; } \\
\text { Friendly spaces; } \\
\text { Friendly architecture; } \\
\text { Architecture; } \\
\text { Environmental quality. }\end{array}$ & [ Architecture ] \\
\hline & & $\begin{array}{l}\text { Methodological instruments; } \\
\text { Methodological issues; } \\
\text { Innovative techniques; } \\
\text { Research methods. }\end{array}$ & [ Methodology ] \\
\hline & & $\begin{array}{l}\text { Active participation; } \\
\text { Voices of children; } \\
\text { Children's preferences; } \\
\text { Research conducted with children; } \\
\text { Children's preferences; } \\
\text { Children as subjects; } \\
\text { Children as respondents; } \\
\text { Children's Participation; } \\
\text { Children's responses. }\end{array}$ & $\begin{array}{l}\text { [ Children's } \\
\text { participation ] }\end{array}$ \\
\hline Databases & $\begin{array}{l}\text { Scope of search in } \\
\text { relevant journals. }\end{array}$ & $\begin{array}{l}\text { Web of Science - Main collection } \\
\text { (Clarivate Analytics) }^{4} \\
\text { Scopus (Elsevier) } \\
\text { Science Direct (Elsevier) } \\
\text { Scielo }^{6}\end{array}$ & \\
\hline Language & $\begin{array}{l}\text { Languages } \\
\text { included. }\end{array}$ & $\begin{array}{l}\text { Portuguese; } \\
\text { English; } \\
\text { Spanish. }\end{array}$ & \\
\hline Period & 10 years & 2009 until 2019 & \\
\hline
\end{tabular}

Source: Queiroz (2019).

${ }^{4}$ Available at: http://apps.webofknowledge.com. Access on: Sep. 11, 2019.

${ }^{5}$ Available at: https://www.scopus.com. Access on: Sep. 11, 2019.

${ }^{6}$ Available at: https://www.sciencedirect.com. Access on: Sep. 11, 2019.

${ }^{7}$ Available at: https://www.scielo.org. Access on: Sep. 11, 2019. 
Table 2 - Paper eligibility criteria

\begin{tabular}{|l|l|}
\hline \multicolumn{1}{|c|}{ Inclusion } & \multicolumn{1}{c|}{ Exclusion } \\
\hline \multirow{4}{*}{$\begin{array}{l}\text { Methods that consider } \\
\text { the opinion of CDS. }\end{array}$} & CDS were not heard; \\
\cline { 2 - 2 } & Research involving only adolescents and/or adults with DS; \\
\cline { 2 - 2 } & Literature review on adverse subjects; \\
\cline { 2 - 2 } & User involvement in health research and treatment; \\
\cline { 2 - 2 } & Clinical tests, examinations, evaluations or analyses; \\
\cline { 2 - 2 } & Review of clinical documentation (medical records) \\
\cline { 2 - 2 } & Method, test or experimentation specific to another area of knowledge. \\
\hline
\end{tabular}

Source: Queiroz (2019).

Specifically with regard to CDS, including infants, 148 articles were found. Many of these were literature reviews, but most were related to health research, which performed tests, analyses, examinations and clinical evaluations. They were asked to develop some activity while being observed, they were analyzed and tested, often through standard tests such as: "Children's Communication Checklist” (SMITH; NÆSS; JARROLD, 2017); "[...] the computerized version of the Profiling Elements of Prosody for Speech and Communication [...]" (STOJANOVIK, 2011, p. 148); and the "Student- and Educational Tracking system Technical reading class [...]" (VAN TILBORG et al., 2018, p. 3).

Among the other articles, the most common activity was the application of instruments to parents, many directed to the difficulties faced or experiences they had. In the few articles that focused on the child, and in which clinical tests or standard performances were not used, the main method of investigation was observations, in some cases with image and audio recordings- whose content was later analysed by the researchers (ENGEVIK; NÆSS; HAGTVET, 2016; CHICON et al., 2019).

\section{Complementary literature review}

The extensive SLR carried out barely contributed to the construction or improvement of the intended research instruments. For this reason, it was decided to look for other sources of information, however this time through a less restrained search in terms of sources and coverage period. This complementary literature review involved books and academic papers based on Goulart and Sperb (2008), Sigaud et al. (2009), Abate (2011), Stojanovik (2011) and Chicon et al. (2019) that addressed methodological instruments applied to young children, mainly in the areas of Architecture, Psychology, Education and Sociology, which proved to be fundamental for the continuity of the work.

\section{Methodological approach}

The research was exploratory and qualitative. The methodological approach (Figure 1) comprised:

(a) three stages related to the study preparation: systematic literature review, complementary literature review, contact with participating institutions and panels of specialists; and

(b) a stage to develop the instruments to be applied to small CDS (4 to 7 years old), which have the following phases: conception, pretests, analysis, corrections, new application and analysis of results.

In view of the proposed theme, the other methods related to architecture were pursued, such as Design Science Research and the ethnographic method; however, in the absence of works with an emphasis on children (and especially CDS), these approaches were discarded.

In order to reach a larger number of specialized professionals and obtain differentiated characteristics and practical knowledge, four institutions specialized in the care of children with intellectual disabilities were invited to take part in the study. The institutions' mode of action and built environment are different:

(a) two of them offer clinical care;

(b) he third one adds clinical and pedagogical care; and

(c) the fourth only provides pedagogical care, before/after school hours.

All of them rely on the work of professionals specialised in disabilities or special education, and accepted the invitation to participate in the research. 
The empirical activity began with the panels of specialists. This comprised consultations with 28 institutional professionals ( 8 psychologists, 4 occupational therapists, 6 speech therapists, 3 physiotherapists, 3 social workers and 4 pedagogues) and 10 parents of the children assisted, who participated, respectively, in individual interviews and focus groups. They allowed greater understanding on issues such as:

(a) communication limitations of CDS;

(b) main activities developed;

(c) better ways of approaching and interacting with them;

(d) perception, qualification, orientation and spatial location of CDS; and

(e) characteristics of an adequate space for them (QUEIROZ; ORNSTEIN; ELALI, 2017).

All professionals contributed to the construction of the instruments, highlighting their area of knowledge. Speech therapists, for example, provided information on the communication of CDS, while psychologists, social workers, and educators highlighted the best ways to approach and interact with CDS. However, the physiotherapists focused on spatial perception and qualification, and spatial orientation and location, while occupational therapists clarified aspects related to children's cognition, perception and psychomotor skills.

The CDS approach instruments were selected, adapted and/or created throughout the study, with a special interest in people-centered instruments (in this case, CDS) applied by psychologists and educators. Some of the methods and techniques identified were those that showed the potential to be used in research in the Architecture and Urbanism areas (Table 3). The methods/techniques characteristic of the Post-Occupancy Evaluation (POE) were added to this set of information (Table 4).

As the children participating in the research have cognitive difficulties, it was decided to adopt research instruments with a playful character, according to the precepts of environmental psychology, pedagogy and architecture and urbanism. From this perspective, there was no intention to make CSD fully aware of their role in an investigation. It was sought to provide them with an opportunity to identify an object similar to the physical environment in which they found themselves, and to identify with it (and children do this very well). The mediation of the toy for access to reality from a child's point of view is the principle that underlies play therapy (MORAIS, 2011), which is adopted in other activities with children (with or without cognitive impairment). According to this line of thought, when playing, the child uses and signifies the elements of his/her daily life, providing information that can be reinterpreted by researchers. Therefore, it is not essential to require the participant to understand the toy as a representation of reality, because getting involved in "make-believe" is what matters. This is, in fact, the way any child reacts to a playful situation, since the idea of 'representation of the real' is extremely complex. According to Jean Piaget, in general abstract thinking (in which the awareness of representations is inserted) it is only built in an advanced stage of human development (ELKIND, 2009; TERRA, 2020), around 12 years of age.

Figure 1 - Methodological approach

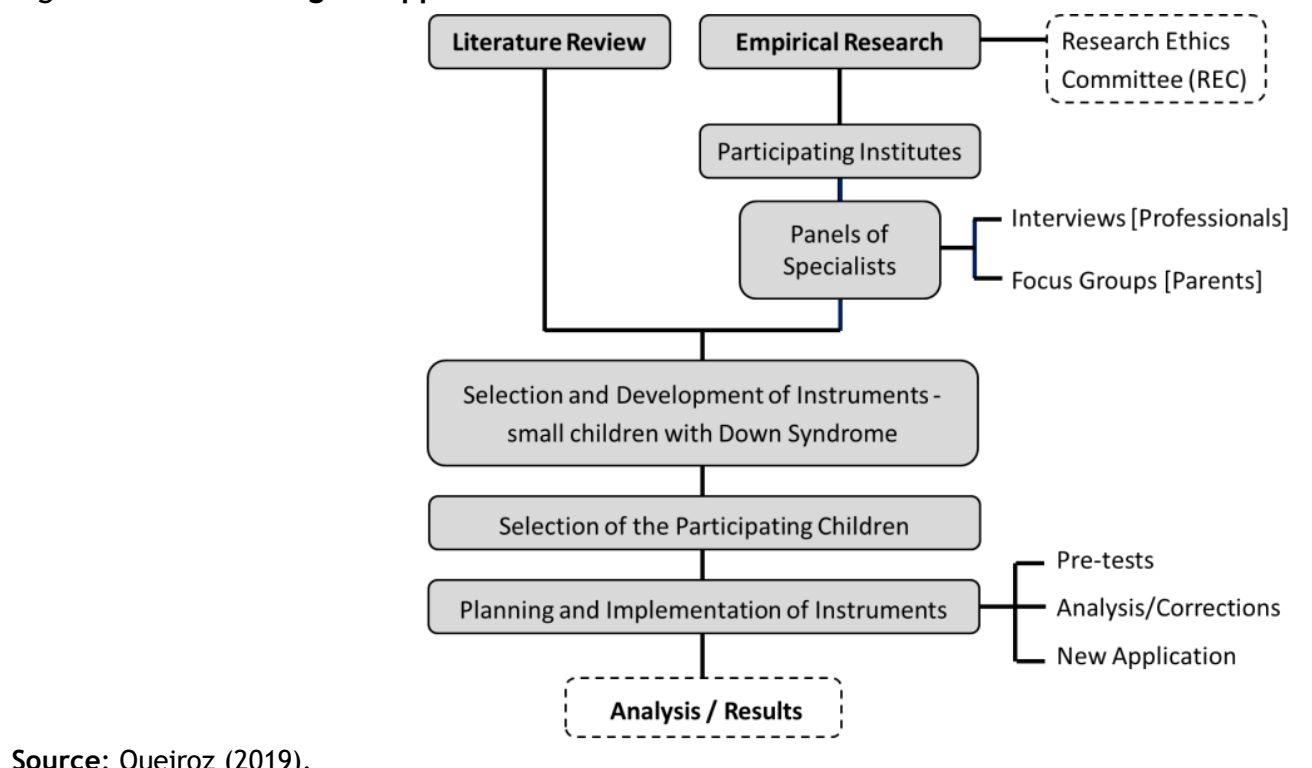

Source: Queiroz (2019). 
The study was submitted and approved by Brazilian research ethics committees ${ }^{8}$. The following were devised: Informed Consent Terms (ICT) delivered to the interviewees and focus group participants; Free and Informed Assent Term (FIAT), delivered to the children; and specific ICT for the responsible parts.

\section{Instruments}

Three instruments were developed to understand the environmental perception of CDS between 4 and 7 years of age, especially on their perception of the environment and satisfaction with spatial quality, and to answer the five questions listed above:

(a) Spatial Qualification Board;

(b) Illustrated Cards; and

(c) "Make-believe" in a Three-Dimensional Physical Model.

Since presenting these research instruments is the main objective of this paper, their description will be detailed below. A clearer detail of these instruments and the results obtained can be found in the developed thesis (QUEIROZ, 2019).

Table 3 - Methods and techniques used in investigations with children carried out in Psychology, Education and Sociology

\begin{tabular}{|c|c|}
\hline Themes & Method/Technique \\
\hline \multirow{3}{*}{ Interview } & Individual interview \\
\hline & Informal conversation \\
\hline & Group interview \\
\hline \multirow{4}{*}{ Group activities } & Discussion group \\
\hline & Focus Group \\
\hline & Group meeting \\
\hline & Semi-structured session \\
\hline \multirow{4}{*}{ Games } & Games, toys and fun activities \\
\hline & Games and toys room \\
\hline & Game and individual box \\
\hline & House building game \\
\hline \multirow{3}{*}{ Image archive } & Photography \\
\hline & Filming \\
\hline & Document analysis \\
\hline \multirow{6}{*}{ Stories } & Weaving stories ${ }^{9}$ \\
\hline & Play Narrative \\
\hline & Story to complete \\
\hline & Photo-based story \\
\hline & "Make-believe" \\
\hline & Three characters \\
\hline \multirow{8}{*}{ Artistic Proposals } & Artistic Representation \\
\hline & Drawing, writing and dialogue \\
\hline & Drawing and oral description \\
\hline & Do-it-yourself session \\
\hline & Drawing \\
\hline & Painting and drawing \\
\hline & Psychodrama \\
\hline & Scribble Game \\
\hline
\end{tabular}

Source: Queiroz (2019).

\footnotetext{
${ }^{8}$ In Portuguese: Comitê de Ética em Pesquisa - CEP, represented by Plataforma Brasil - available at: http: //conselho.saude.gov.br/plataforma-brasil-conep.

${ }^{9}$ WEAVING STORIES (KARLSSON, 2008): individually or in a group, the child tells a story of his or her choice and the adult writes it exactly as it was told, without asking questions, suggesting improvements or requesting explanations.
} 
Table 4 - Methods and techniques used in investigations with children carried out in the POE

\begin{tabular}{|c|l|}
\hline Themes & \multicolumn{1}{|c|}{ Method / Technique } \\
\hline \multirow{2}{*}{ Interview } & Playful Interview \\
\cline { 2 - 2 } & Visual Selection \\
\cline { 2 - 2 } Observation & 3D Questionnaire using tactile mockups \\
\cline { 2 - 2 } & Naturalistic Observation \\
\cline { 2 - 2 } Artistic Proposals / History & Participant observation \\
\cline { 2 - 2 } & Pental Map \\
\cline { 2 - 2 } & Drawing-Story \\
\hline \multirow{2}{*}{ Oresires } \\
\hline
\end{tabular}

Source: Queiroz (2019).

Figure 2 - Spatial Qualification Board - Instrument I (original instrument in Portuguese)

\section{WHAT DO YOU LIKE MOST?}
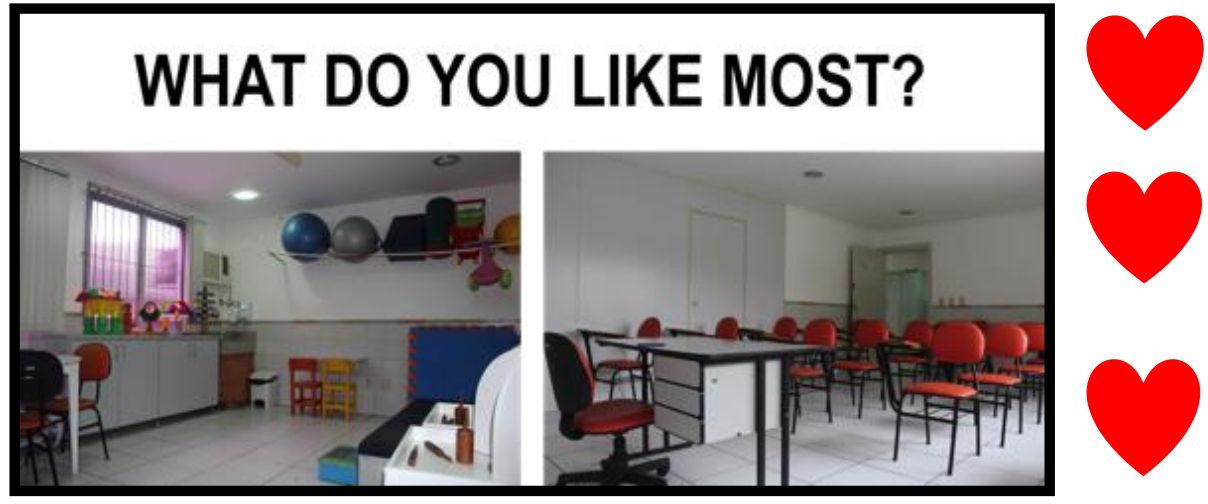

Source: Queiroz (2019).

The instrument 1 - Spatial Qualification Board (Figure 2) corresponded to a board with two same-size photographs placed side by side, and the question: "What do you like most". The two environments presented were real and known (familiar to the child). The selection was accomplished by gluing an adhesive heart above the favorite photograph. Given the possibility of the participant only wanting to quickly "stick" without actually answering the question, 2 to 3 hearts per child were provided, one at a time. If he/she stuck the first heart in one photograph, and the second in another, the third adhesive was given, informing the child that it would be the last one, so that he/she would actually chose one of the environments.

This instrument was inspired by two methods/techniques: Visual Selection (SANOFF, 1991) and games, toys and fun activities (ARFOUILLOUX, 1976). In its development, the literature and the panel of experts also contributed. The first helped with strategies for interaction and obtaining answers from children, indicating the following was required:

(a) let the child handle the material freely;

(b) propose activities of interest to the child;

(c) propose activities that stimulate them;

(d) propose toys and activities that result in some type of action; and

(e) propose toys and activities that are fun and creative.

The expert panel contributed with the following recommendations:

(a) photograph opposing environments and offer the child comparisons to choose the one that most appeals to them;

(b) always use real figures - photographs, rather than illustrative images or drawings, as the children think very concretely and have difficulty making associations;

(c) show response options (images) so that the child points to the answer of the question; 
(d) insert elements that facilitate the answer and make the "questions and answers game" more fun - e.g. happy face and sad face; "like" and "dislike" signs; yellow, green and red signs; and

(e) after the child experiences the situation, ask them to draw what they like best, or present illustrations on a board and ask the child to select their preferred option - all related to the previous experience (concrete experience).

The instrument 2 - Illustrated Cards (Figure 3) has a playful nature, resembling a game of cards, with real pictures of furniture, objects and toys. In this instrument, the child was asked to identify which cards indicated elements belonging to the environment they were in. Twelve individual cards with pictures of furniture, objects and toys from the room in which they were in (Room 22) and the same number of images of other environments of the institution were handed to the child (cards belonging to and not belonging to the room in question).

This second instrument was inspired by the Visual Selection method (SANOFF, 1991). In its development, the literature and the panel of experts also contributed. The first assisted with strategies for interaction and to obtain responses from children, indicating the following:

(a) let the child handle the material freely; and

(b) propose activities that stimulate them.

The expert panel contributed with the following recommendations:

(a) always use real pictures - photographs, rather than illustrative images or drawings, as children think very concretely and have difficulty making associations; and

(b) carry out the activity together with the child to attract the child's interest.

In order to understand the imagination of the CDS, the third instrument - "Make-believe" in a ThreeDimensional Physical Model (Figure 4) was developed, and prioritizes the playful aspect and the "makebelieve", allowing the child to play and reflect on the environment he/she is inserted in. The instrument consisted of a realistic three-dimensional model (mockup) of a place familiar to the child. The aim was to observe if the CDS associated the real size to the miniature one shown, as well as to verify if they recognized the elements in the real space they were in. By inserting a human figure, on an appropriate scale, using propped up paper-characters, the intention was to add the "make-believe" to the investigation, in order to obtain relevant information about "liking" and what was "preferred" within the place. Thus, trying to answer the other questions established - What would the characteristics be of a space suitable for them? What do they like in a place? What do they not like in a place? What bothers them?

This instrument was inspired by the following methods/techniques:

(a) 3D questionnaire with tactile model (ABATE, 2011);

(b) Games, Toys and Fun activities (ARFOUILLOUX, 1976);

(c) House-Building Game (ABERASTURY, 1982);

(d) Play Narrative (GOULART; SPERB, 2008); and

(e) "Make-Believe" (ABERASTURY, 1982).

In its development, the literature and the panel of experts also contributed. From the first, strategies for interaction and to obtain responses from children were obtained, such as:

(a) let the child handle the material freely;

(b) propose activities of interest to the child;

(c) propose activities that stimulate them;

(d) propose toys and activities that result in some type of action; and

(e) propose toys and activities that are fun and creative. 
Figure 3 - Illustrated Cards - Instrument II

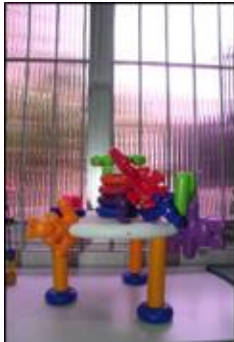

(a) *Fitting cubes toy

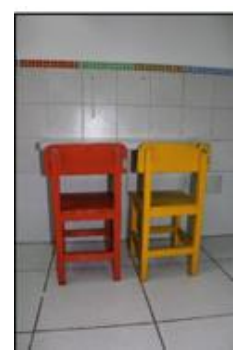

(g) *Table with colored chairs

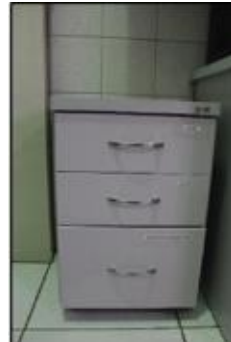

(b) *Commode

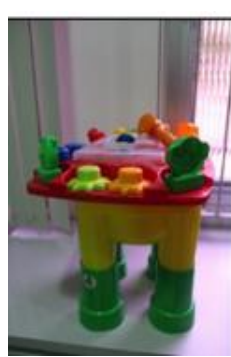

(h) *Number game toy

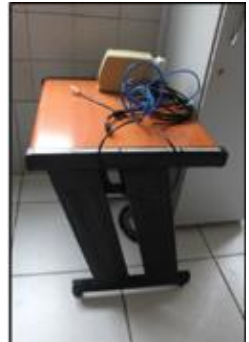

(c) Table with wires on top

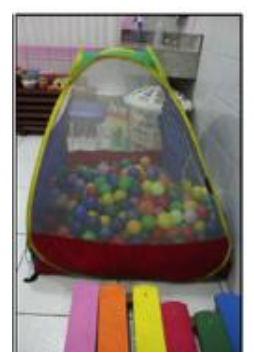

(i) Ball pool

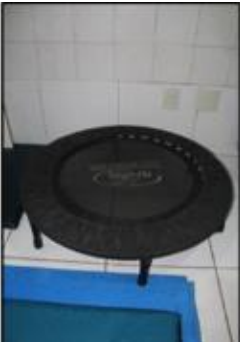

(d) Trampoline

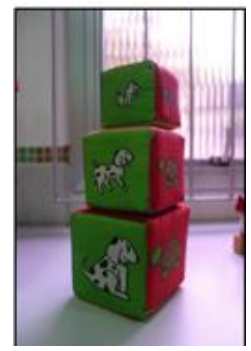

(j) *Pyramid blocks

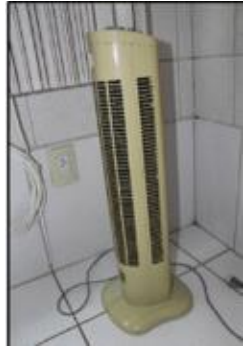

(e) Fan

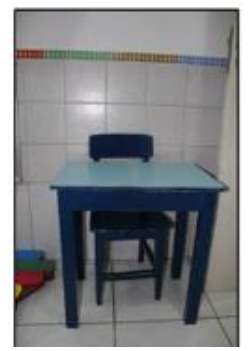

(k) Table with blue chair

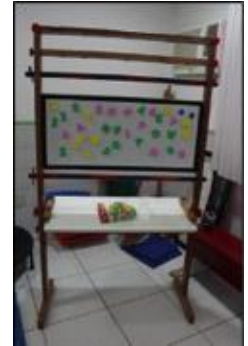

(f) Alphabet, work game toy table

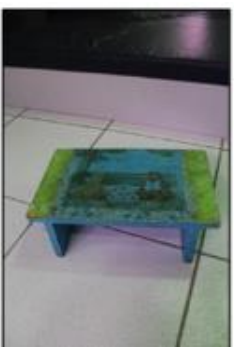

(1) *Florest

Source: Queiroz (2019).

Note: *Images belonging to Room 22 .

Figure 4 - Three-Dimensional Physical Model of Room 22 - viewed from above

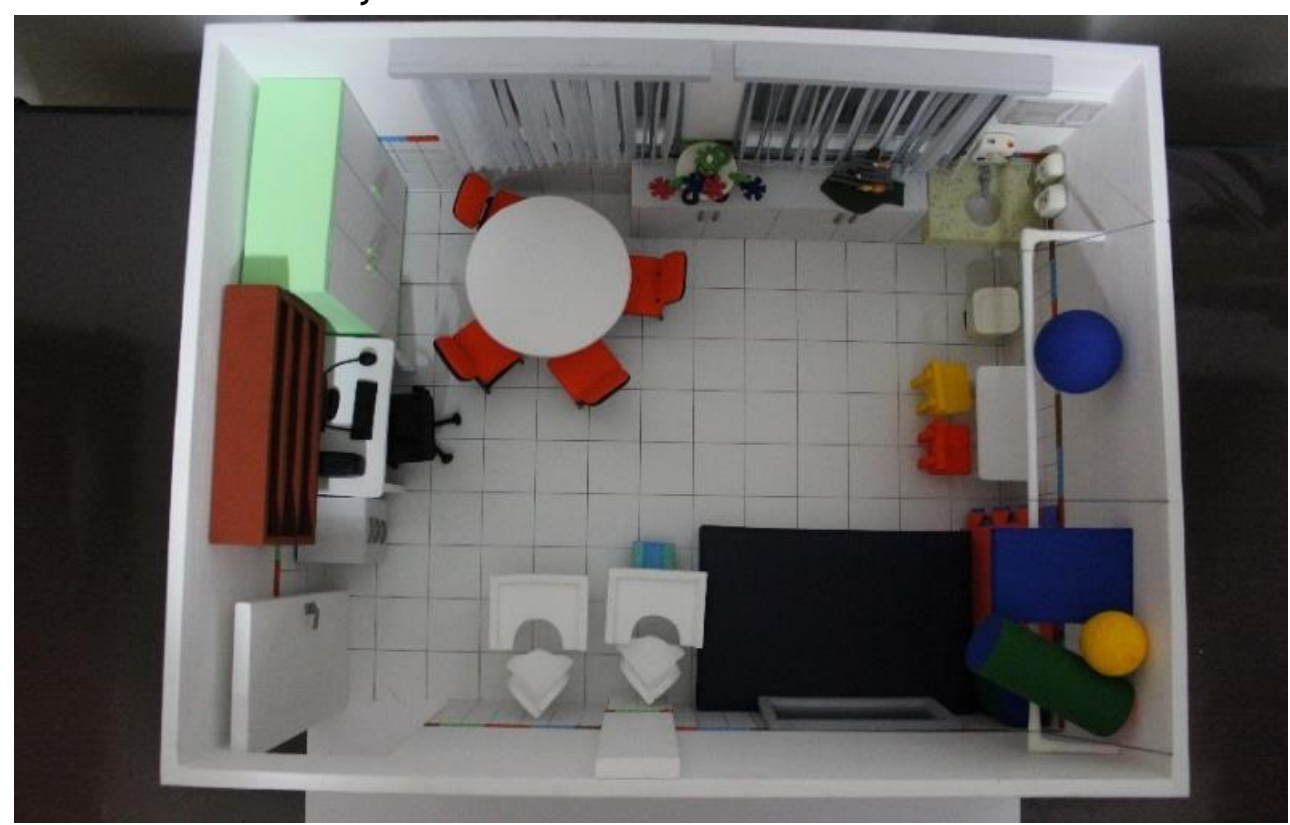

Source: Queiroz (2019).

The expert panel contributed with recommendations on the following:

(a) real experimentation, testing situations through simulations, where children can experience the spaces they want to test;

(b) Simulation using the "Make-Believe", with nearby objects, simulations of environments and dolls, making the experience very palpable and concrete for the child - play with the child and try to obtain the desired answers; 
(c) ask the child to do something, asking questions while he/she carries out the activity in the game, always in a playful manner;

(d) have informal conversations while he/she is distracted by some activity;

(e) use "make-believe" with dolls, superheroes, and puppets - the child simulates past real situations, repeating gestures and even conversations they witnessed, revealing some information;

(f) insert the specific interest of the child in the programmed activities;

(g) carry out the activity together with the child to attract the child's interest;

(h) excite their curiosity; and

(i) tactile and visually stimulate objects they can explore.

The physical model was produced on a 1:10 scale, with materials considered to be safe (no sharp tips to avoid cutting). It was intended to facilitate understanding by the CDS and enable comfortable handling: floor and walls using $10 \mathrm{~mm}$ wooden boards, with door and window sills; furniture and objects made of foam board, biscuit, Ethylene Vinyl Acetate (EVA), acetate and aluminum paper, fine line and fabric; the door was secured with high strength tape that allowed opening/closing; the windows were affixed and made of transparent acetate paper and had blinds. Almost all the furniture was mobile and could be handled freely. The most fragile pieces, such as chairs and tables, had spare parts for immediate replacement.

\section{Recommendations and strategies for applying the instruments}

The following recommendations of the parents and professionals, and the strategies obtained in the theoretical review were generally considered for the development of the three instruments described:

(a) use visual aids;

(b) carry out the activities in an environment the child is familiar with and which he/she dominates;

(c) be patient and repeat the information, since children have difficulty with immediate auditory memory;

(d) ask the same question at least twice, modifying the inquiry order, as a form of confirmation, to divert echolalia and other common defenses to children;

(e) modify the question while maintaining content, but carrying out two or three different approaches to ensure that the child responds to what he thinks;

(f) go beyond the question itself, be creative, use tricks, especially visual ones;

(g) use playful situations, adding toys and games to the direct questions;

(h) offer only one activity at a time, so that they pay attention;

(i) provide a model of what should be accomplished, or perform the activity together with the child;

(j) assist when necessary, so that the child does not become discouraged; but wait for the child's response time, instead of filling the silence with one's own speech;

(k) explain in advance each step of the activities to be developed;

(1) provide few, clear and precise instructions;

(m) use simple language, with short sentences and concrete information;

(n) keep any stimuli, other than those of the activity in question, in closed cabinets, in order not to distract the participants;

(o) reward them positively, with a smile, a gesture of approval or a few words of praise while executing the activities; and

(p) stimulate them constantly, offering varied and short-lived activities, since these children have little concentration and are easily sidetracked.

For organization, preparation and programming, just one application site was selected for the third instrument, as it is not feasible to develop several three-dimensional models. In addition, it was also necessary to select the rooms to be photographed for the other two instruments, which should be familiar to the children (recommendation of parents and professionals). Therefore, it was decided to focus the study in 
an environment that was used by most of the CDS assisted in "Institution A"10, which authorized the application of the instruments in their facilities.

First, a complete list of CDS assisted by the institution, which had the desired characteristics, was obtained. Based on the selection of these children, the professionals and specialties that attended them were identified, as well as the days and times of their visits and the rooms used. All of this information enabled to determine Room 22 as the research object, and consequently, the inspiration for the Physical Three-Dimensional Model.

As there was no other familiar environment for the children, somewhat different from Room 22 , for the application of Instrument I, it was decided to add to the instrument in question a previous experience in a meeting room of the institution, characterized as a traditional classroom. After the experience, the child was asked to choose between the two environments through the photographs.

Once the environments were chosen, the instruments were prepared for the application and to select the participating children: eleven boys and girls aged between four and seven years, incomplete, verbal or nonverbal, with or without comorbidities, all attended to at some point in Room 22 of Institution A.

\section{Ethical concerns}

The research was submitted to the Research Ethics Committee (process n. 51657415.0.0000.0076 approved in 11/12/2015), and children's participation guaranteed by the Informed Consent Form and Child Consent Form. Guaranteeing their anonymity, in the article the participating children received generic identification (Figure 5), which differentiates them, but preserves the established ethical precepts.

\section{Application of instruments}

Initially, pre-tests were carried out with three children, and after analyzing this first experiment, small changes were made in the application of the instruments. As these changes would not incapacitate the final results, they did not justify the elimination of these participants from the final study, given the small number of children eligible to participate.

Also as a consequence of this first phase, it was decided to divide the participants into three groups in order to test different interaction and application forms with those involved, as it is an exploratory study (Table 5):

(a) the first two groups, consisting of five children in total, performed all the activities in a single day;

(b) the pre-test children were in the second group, experiencing a second encounter, where all activities were performed again; and

(c) for the third group, comprising six children, the first meeting was to meet the researcher and the physical model, when they were stimulated to touch it and to make associations with the real space; in the second meeting, all the planned instruments were applied.

The instruments were applied between November 6 and 23, 2017, with an average duration of 50 minutes. Room 22 was prepared before each application, taking into account one more recommendation from the experts: "Remove the stimuli from the environment." To do so, all materials of other activities were placed in an appropriate place, away from the children's sight and reach, cabinets and drawers were locked or sealed with tape.

The activities were filmed (video) by a photographer, always with the authorization of the responsible parties. Two children did not feel comfortable with the presence of the photographer, who was then asked to leave. The video recording was performed in all cases because the camera was positioned in a strategic location, not perceived by the children. After each meeting, the researcher recorded an audio describing the sensations and details of the session. This in turn created a field diary that, in addition to photos and films, led to writing detailed descriptions about the meetings with the children and also identifying relevant information.

\footnotetext{
${ }^{10}$ Fantasy name given to one of the participant institutions in the research.
} 
Figure 5 - Explanatory caption of the identification of the CDS participants

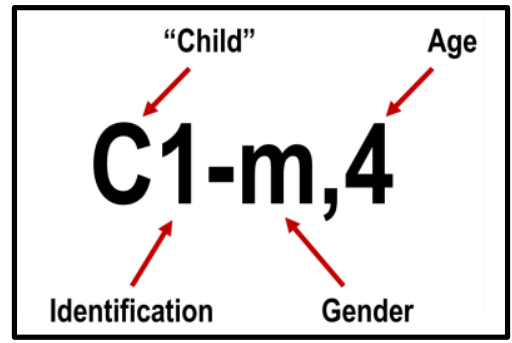

Source: Queiroz (2019).

Table 5 - Classification of participants according to the way of applying the instruments

\begin{tabular}{|c|c|c|}
\hline GROUP 01 & GROUP 02 & GROUP 03 \\
\hline \multirow{2}{*}{ C1-m,4 } & C3-m,5 & C6-m,5 \\
& C7-m,5 \\
& C4-m,5 & C8-m,6 \\
C2-m,5 & C5-f,6 & C10-m,4 \\
& C11-f,4
\end{tabular}

Source: Queiroz (2019).

\section{Results}

Developing research instruments for investigating the physical environment from the point of view of children with Down Syndrome proved to be a challenge, in which the range of possibilities generated by the panel of experts was considered, although reduced. Among the various existing possibilities, three types of instruments were selected based on their adherence to the AU area, the limitations and complexity of the research (including in terms of time and available resources) and, above all, the search for a playful instrument, children friendly.

Using the proposed activities, we were able to respond (even if partially) to the issues initially set. The participants demonstrated that they perceive space in all activities:

(a) in Instrument I, by pointing to objects in the photograph and associating them with real objects, pointing to them, or pointing to the swivel chair of the boardroom, special attraction of the new open room;

(b) in Instrument II, when identifying the objects in the room they were in, demonstrating knowledge of what was in the room they are familiar with; and

(c) and Instrument III by associating the miniature and real size.

Certainly some of them were more attentive than others, or more willing to respond, but, in general, the children demonstrated they perceived the space, paying attention to objects and furniture, and indicating preferences through identifications (mainly toys).

As for qualifying environments, Instrument I showed that most participants were able to do it quite easily, as they pasted the sticker in their favorite environment without hesitation. In addition, most justified their choice by pointing to the furniture or toy seen in the images, and even touching their chest, a sign of "liking". Among the children who performed the activity in the two meetings (Group 02), the two who changed their mind (selecting different photographs), justified the choice when questioned, in the second application.

With regard to clear indications concerning the characteristics of the environment, few children were able to do so through Instrument III, in which they signaled whether or not they liked the elements of the model, such as tatami, containment chair, and colored wooden table and chairs. 
On the other hand, in the application of Instrument I, when they glued adhesives on the objects, the children demonstrated to like some of the elements that were present in the environment, including indicating them as favorites, which shows that there is some discrimination between them. Such preferences have been reported by parents and professionals, whose daily experience with children widens the range of information available about them.

In addition, the importance of behavioral information is emphasised, since the participant's observation during the application of the instruments and informally (between sessions and during recreation hours) allowed us to understand a little about the relationship of these children with the place. They represent simple knowledge that can make a difference in future contacts, such as:

(a) the excess of stimuli gets in the way of their concentration and participation, because they are usually very dispersed/distracted;

(b) any physical discomfort bothers them greatly (from the clothes and shoes they wear at that moment to the conditions of room temperature, luminosity, noise and ergonomics of furniture), hindering their involvement in any activity; and

(c) they have difficulty dealing with unfamiliar environments and people, which is better dealt with in places that are familiar to them.

However, the great familiarity with a place may make them want to repeat previous experiences that occurred there, which may not be favorable to the development of a new activity.

It is noteworthy that some of the information collected would not have been obtained through nonparticipatory methods. Parents and professionals do not know, for example, the preference of CDS for objects, furniture or rooms, nor do they identify undisclosed discomforts regarding a containment chair. They also do not conduct experiments to discover preferences or repulsions, they just observe the experiences lived out in everyday life. Thus, the participatory methods allow them to experience situations and observe the child's response to the unexpected, as well as to ask them about one or another reaction. Only children themselves can make us understand certain issues (BORGERS; LEEUW; HOX, 2000), including their thoughts regarding the environment.

\section{Discussion and final remarks}

The objective of this paper is to present an experience of developing research instruments directed to children with Down Syndrome in order to obtain their opinion about the built environment. The biggest challenge faced was the contact with these children, who, as demonstrated by the literature review, has not been fully addressed in the investigations. The instruments developed have a playful characteristic, with games and models adapted to the requirements and needs of that group. Although this type of research instrument can be used in investigations with other children and even adults, in the case of CDS, special attention was required regarding how to create and apply them, as well as specific care regarding time and the mode of data collection. It is precisely in these points that the importance and innovation of the research carried out resides.

The exploratory and qualitative study showed that it is possible to apply research instruments to CDS in order to investigate their satisfaction with the environment. Therefore, there is a path for new works, of a confirmatory and experimental nature, which can deepen knowledge in this field. On the other hand, the study presented limitations that need to be recognized:

(a) little time available for the researcher to be with the child. The researcher had only the limited time for consultation to carry out the proposed activities, totaling 50 to 60 minutes for child-researcher recognition and application of the three instruments;

(b) inability to prepare the environment as desired for the research. Since the meetings with the children were held in the consultation room of the occupational therapist, it was not possible, for example, to remove the various visual stimuli in the environment, or to seal cabinets and drawers. This issue, alerted by the panels of experts and theoretical review, facilitated the children's dispersed attention, who were interested in the toys exposed, and tried to break away from activities by opening the toy cabinets or drawers with the drawing material;

(c) the Meeting Room, used for comparison with Room 22 in the first activity, needed to be reorganized every day by the researcher. Because in its original configuration the chairs were arranged in a circle for 
meetings with the professionals of the institution, and the photograph presented to the children showed a configuration similar to that of a traditional classroom, with the chairs arranged in rows; and

(d) reduced number of participants. The children targeted by the research needed to be seen in a specific room of the institution in question, due to the physical model developed and the need for familiarity with the environment. Therefore, the researcher had a restricted number of children, which can generate strong biases and mask some results. However, since the research was exploratory and not confirmatory, this limitation did not put a stop to the study.

These difficulties were obstacles to the development of the research, but they did not prevent it. Certainly avoiding such obstacles could facilitate the progress of the research, and may even promote greater and/or better discoveries, which are suggested for new activities in this field.

It should also be noted that participatory methods should be added to others, defining: "A multi-method approach, so that data gathered from very young children can be supplemented and contextualized with data gathered by adults (particularly those who know the child well) [...]" (SHAW; BRADY; DAVEY, 2011, p. 17).

When considering the obtained results, it was verified that the methodological instruments developed proved to be adequate to the investigated problem. This allows a simpler application, as well as an uncomplicated manipulation and interpretation of the data collected. Adopting multiple methods was essential to achieve the desired objectives, making it possible to answer the questions proposed by the research through the cross referencing of the obtained data. In addition, it also allowed good approximation between child and researcher, which corresponded to gradual knowledge from the first instrument applied, leading to a greater interaction and still better perception of each child's response mode, given that the time available with each child was limited (as discussed earlier).

Preparatory meetings are essential, but they should avoid the introduction of actual inquiry instruments so that the novelty effect is preserved for users or participants. It is necessary to carry out these meetings as a way to get to know the child, his behavior and his way of communicating, as well as allowing the child to trust the researcher, improving their relationship, which would facilitate accomplishing the proposed activities.

It is also important to observe the behaviour of the children participating in the environment in which the instruments will be applied, away from the presence of the parents. This is the only way to verify what is accomplished in the environment in question, how they interact with the environment and with the professional who knows them and who they trust. This procedure may help understand some of the behaviours revealed during the development of the research activities (whether they are due to the routine or not) and possibly prevent them. Professionals can also ensure that the child is comfortable and facilitate communication between child and researcher (SHAW; BRADY; DAVEY, 2011). These participants' observations may also benefit the child's previous knowledge, as well as the information collected through the questionnaire sent to the parents.

It is emphasised that expert panels and literature indications were essential for the development and application of the methodological instruments, which confirms the importance of the association between theory and practice, in a collaborative activity.

In general, it is understood that the research contributed to its advancement in the area with respect to the development of data collection instruments applied to small children in the context of intellectual disabilities, insofar as, based on the recognition of research methods and techniques, ways of approaching this audience were proposed and their applicability were tested. However, the major contribution is to pave the way for a real possibility to value small children with Down syndrome and make them the central figure of the research, making them active speakers, and allowing them to inform their tastes, their desires, their aspirations, all the more when this is spatial qualification.

The relevance and adequacy of exploratory research to this object of study is reiterated, since the results to be achieved and initially proposed - raising questions for future academic-scientific studies - were successful. Thus, there is a greater probability for the inclusion of these children's opinions in future research with regard to the spatial quality to be developed in Post-Occupancy Evaluation (POE) and, more broadly, in the fields of Architecture and Urbanism. 


\section{References}

ABATE, T. P. Instrumentos de Avaliação Pós-Ocupação (APO) adaptados a pré-escolares com deficiência física, auditiva e visual. São Paulo, 2011. Tese (Doutorado em Arquitetura e Urbanismo) Faculdade de Arquitetura e Urbanismo, Universidade de São Paulo, São Paulo, 2011.

ABATE, T. P.; ONO, R.; ORNSTEIN, S. W. Ética em pesquisa de APO. In: ONO, R. et al. (org.). Avaliação Pós-Ocupação na arquitetura, no urbanismo e no design: da teoria à prática. São Paulo: Oficina de Textos, 2018.

ABERASTURY, A. Psicanálise da criança: teoria e técnica. Porto Alegre: Artmed, 1982.

ALTMAN, I.; WOHLWILL, J. F. (ed.). Children and the environment. New York: Plenum Press, 1978.

ARFOUILLOUX, J. C. A Entrevista com a criança: a abordagem da criança através do diálogo, do brinquedo e do desenho. Rio de Janeiro: Zahar Editores, 1976.

AZEVEDO, G. A. N. Arquitetura escolar e educação: um modelo conceitual de abordagem interacionista. Rio de Janeiro, 2002. Tese (Doutorado em Engenharia da Produção) - Escola de Engenharia, Universidade Federal do Rio de Janeiro, Rio de Janeiro, 2002.

BONIS, S. A.; SAWIN, K. J. Risks and protective factors for stress self-management in parents of children with autism spectrum disorder: an integrated review of the literature. Journal of Pediatric Nursing, v. 31, n. 6, p. 567-579, nov. 2016.

BORGERS, N.; LEEUW, E.; HOX, J. Children as respondents in survey research: cognitive development and response quality. Bulletin de Méthodologie Sociologique, v. 66, p. 60-75, 2000.

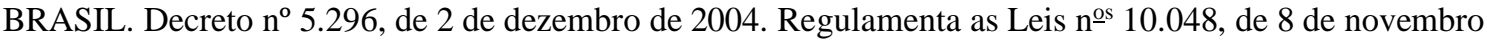
de 2000, que dá prioridade de atendimento às pessoas que especifica, e 10.098, de 19 de dezembro de 2000, que estabelece normas gerais e critérios básicos para a promoção da acessibilidade das pessoas portadoras de deficiência ou com mobilidade reduzida, e dá outras providências. Diário Oficial da União, Brasília, 2004.

BRUNONI, D. Aspectos epidemiológicos e genéticos. In: SCHWARTZMAN, J. S. (org.). Síndrome de Down. São Paulo: Mackenzie - Memnon, 1999.

CAIXETA, M. C. B. F.; LUKIANTCHUKI, M. Avaliação Pós-Ocupação em creche: uma abordagem sobre os instrumentos de avaliação utilizados. In: SIMPÓSIO BRASILEIRO DE QUALIDADE DO PROJETO NO AMBIENTE CONSTRUÍDO; WORKSHOP BRASILEIRO DE GESTÃO DO PROCESSO DE PROJETO NA CONSTRUÇÃO DE EDIFÍCIOS, 9., São Carlos, 2009. Anais [...] São Carlos, 2009.

CARDON, T.; AZUMA, T. Visual attending preferences in children with autism spectrum disorders: a comparison between live and video presentation modes. Research in Autism Spectrum Disorders, v. 6, n. 3, p. 1061-1067, 1 jul. 2012.

CARNEIRO, D. A.; VILELA, T. A. Ocorrência de infecções respiratórias agudas em pré-escolares que frequentam creche universitária. São Paulo: Escola de Enfermagem, Universidade de São Paulo, 2006.

CARVALHO, T. C. P. Arquitetura escolar inclusiva: construindo espaços para educação infantil. São Carlos, 2008. Tese (Doutorado em Arquitetura e Urbanismo) - Escola de Engenharia de São Carlos, Universidade de São Paulo, São Carlos, 2008.

CHICON, J. F. et al. Brincando e aprendendo: aspectos relacionais da criança com autismo. Revista Brasileira de Ciências do Esporte, v. 41, n. 2, p. 169-175, 4 jul. 2019.

COLLINS, K.; STAPLES, K. The role of physical activity in improving physical fitness in children with intellectual and developmental disabilities. Research in Developmental Disabilities, v. 69, p. 49-60, 1 out. 2017.

CONSELHO NACIONAL DE SAÚDE. Resolução no 466, de 12 de dezembro de 2012. Brasília: Ministério da Saúde, 2012. Disponível em: https://conselho.saude.gov.br/resolucoes/2012/Reso466.pdf. Acesso em: 01 maio 2020

CROWELL, J. A.; KELUSKAR, J.; GORECKI, A. Parenting behavior and the development of children with autism spectrum disorder. Comprehensive Psychiatry, v. 90, p. 21-29, abr. 2019.

DAI, Y. G. et al. Language abilities in monolingual - and bilingual - exposed children with autism or other developmental disorders. Research in Autism Spectrum Disorders, v. 55, p. 38-49, 1 nov. 2018. 
DE GIULI, V.; DA POS, O.; DE CARLI, M. Indoor environmental quality and pupil perception in Italian primary schools. Building and Environment, v. 56, p. 335-345, out. 2012.

ELALI, G. A. Ambientes para educação infantil: um quebra-cabeça? Contribuição metodológica na avaliação pós-ocupação de edificações e na elaboração de diretrizes para projetos arquitetônicos na área. São Paulo, 2002. Tese (Doutorado em Estruturas Ambientais Urbanas) Universidade de São Paulo, São Paulo, 2002.

ELALI, G. A. Avaliação Pós-Ocupação e responsabilidade social: uma relação a ser sempre (re) discutida. Revista Gestão \& Tecnologia de Projetos, v. 5, n. 2, nov. 2010.

ELKIND, D. The child's reality: three developmental themes. London: Psychology Press, 2009.

EMERSON, E. Self-reported exposure to disablism is associated with poorer self-reported health and wellbeing among adults with intellectual disabilities in England: a cross-sectional survey. Public Health, v. 124, n. 12 , p. 682-689, 1 dez. 2010.

ENGEVIK, L. I.; NÆSS, K.-A. B.; HAGTVET, B. E. Cognitive stimulation of pupils with Down syndrome: a study of inferential talk during book-sharing. Research in Developmental Disabilities, v. 55, p. 287-300, ago. 2016.

ESTELLER MORÉ, E. Estrategia terapéutica y tratamiento médico. Acta Otorrinolaringológica Española, v. 61, p. 49-52, supl. 1, dez. 2010.

FABBRI, K. Thermal comfort evaluation in kindergarten: PMV and PPD measurement through datalogger and questionnaire. Building and Environment, v. 68, p. 202-214, out. 2013.

FARGAS-MALET, M. et al. Research with children: methodological issues and innovative techniques. Journal of Early Childhood Research, v. 8, n. 2, p. 175-192, 2010.

FERNANDES, N. Ética na pesquisa com crianças: ausências e desafios. Revista Brasileira de Educação, v. 21, n. 66, p. 759-779, jul./set. 2016.

FERNÁNDEZ L, M. P.; PUENTE F, A.; FERRANDO L, M. T. Síndrome X frágil: desarrollo e intervención del lenguaje escrito. Revista Chilena de Neuro-Psiquiatria, v. 48, n. 3, p. 219-231, set. 2010.

FRANCISCO, D. J.; BITTENCOURT, I. Ética em pesquisa com crianças: problematizações sobre termo de assentimento. In: SIMPÓSIO LUSO-BRASILEIRO EM ESTUDOS DA CRIANÇA - PESQUISA COM CRIANÇAS: DESAFIOS ÉTICOS E METODOLÓGICOS, 2., Porto Alegre, 2014. Anais [...] Porto Alegre, 2014.

GAIVA, M. A. M. Pesquisa envolvendo crianças: aspectos éticos. Revista Bioética, v. 17, n. 1, p. 135-46, 2009.

GOULART, C. M. T.; SPERB, T. M. Histórias de crianças: as narrativas de crianças asmáticas no brincar. In: CRUZ, S. H. V. (org.). A criança fala: a escuta de crianças em pesquisas. São Paulo: Cortez, 2008.

KARLSSON, L. Tecendo histórias com crianças: uma chave para ouvir e compartilhar. In: CRUZ, S. H. V. (org.). A criança fala: a escuta de crianças em pesquisas. São Paulo: Cortez, 2008.

KONSTANTINOPOULOU, S. et al. Relationship between obstructive sleep apnea cardiac complications and sleepiness in children with Down syndrome. Sleep Medicine, v. 17, p. 18-24, jan. 2016.

KOZMA, C. O que é síndrome de Down? In: STRAY-GUNDERSEN, K. (org.). Crianças com Síndrome de Down: guia para pais e educadores. Porto Alegre: Artmed, 2007.

LIMA, M. S. A cidade e a criança. São Paulo: Nobel, 1989. Coleção Cidade Aberta.

LIN, S. C. et al. Screening for obstructive sleep apnea in children with Down Syndrome. Journal of Pediatrics, v. 165, n. 1, p. 117-122, jul. 2014.

LOTT, I. T. Antioxidants in Down syndrome. Biochimica et Biophysica Acta, v. 1822, n. 5, p. 657-663, mai. 2012.

MARTINS, V. R. et al. Interação com usuários em APO de pátios escolares: métodos, instrumentos e aplicação. In: SIMPÓSIO BRASILEIRO DE QUALIDADE DO PROJETO NO AMBIENTE CONSTRUÍDO, 2.; WORKSHOP BRASILEIRO DE GESTÃO DO PROCESSO DE PROJETO NA CONSTRUÇÃO DE EDIFÍCIOS, 10., Rio de Janeiro, 2011. Anais [...] Rio de Janeiro, 2011. 
MCCONNAUGHEY, F.; QUINN, P. O. O desenvolvimento da criança com Síndrome de Down. In: STRAY-GUNDERSE.N, K. (org.). Crianças com Síndrome de Down: guia para pais e educadores. Porto Alegre: Artmed, 2007.

MORAIS, M. T. C. de. Os significados de ludoterapia para as protagonistas do processo: crianças em atendimento. Natal, 2011. Dissertação (Mestrado em Psicologia) - Programa de Pós-Graduação em Psicologia, Universidade Federal do Rio Grande do Norte, Natal, 2011.

NATALINO, M. L. R.; ÁVILA, V. M. Avaliação Pós-Ocupação de projeto padrão proinfância: uma abordagem multimétodos no CMEI - espaço da infância. 2016. Disponível em: http://pdf.blucher.com.br.s3sa-east-1.amazonaws.com/designproceedings/eneac2016/AMB07-1.pdf. Acesso em: 22 set. 2019.

NUCCI, L. P.; TURIEL, E. Social interactions and the development of social concepts in preschool children. Child Development, v. 49, n. 2, p. 400-407, jun. 1978.

ORGANIZAÇÃO MUNDIAL DA SAÚDE. Relatório Mundial sobre a Deficiência. World Health Organization, The World Bank. São Paulo: SEDPcD, 2012.

PIMENTEL, S. C. Conviver com a Síndrome de Down em escola inclusiva: mediação pedagógica e formação de conceitos. Petrópolis: Vozes, 2012.

PIOVESAN, A.; TEMPORINI, E.R. Pesquisa exploratória: procedimento metodológico para o estudo de fatores humanos no campo da saúde pública. Revista Saúde Pública, São Paulo, v, 29, n. 4, p. 318-325, 1995.

PUESCHEL, S.; REILY, L. H. (org.). Síndrome de Down: guia para pais e educadores. 8. ed. Campinas: Papirus, 2003.

QUEIROZ, V. M. Qualidade espacial para pessoas com deficiência intelectual: investigando modos de obter a opinião de crianças pequenas com Síndrome de Down. São Paulo, 2019. 276 f. Tese (Doutorado em Arquitetura e Urbanismo) - Faculdade de Arquitetura e Urbanismo, Universidade de São Paulo, São Paulo, 2019.

QUEIROZ, V. M.; ORNSTEIN, S. W.; ELALI, G. A. Qualidade espacial para crianças com deficiência intelectual: a contribuição de especialistas. In: SIMPÓSIO BRASILEIRO DE QUALIDADE DO PROJETO NO AMBIENTE CONSTRUÍDO, 5., João Pessoa, 2017. Anais [...] João Pessoa: Ed. Universitária UFPB, 2017.

SANDERS, E. J.; ERICKSON, K. A. Wh - Question answering in children with intellectual disability. Journal of Communication Disorders, v. 76, p. 79-90, nov. 2018.

SANMANEECHAI, O. et al. Treatment outcomes of west syndrome in infants with Down Syndrome. Pediatric Neurology, v. 48, n. 1, p. 42-47, jan. 2013.

SANOFF, H. Visual research methods in design. New York: Van Nostrand Reinhold, 1991.

SANT'ANA, R. B. Criança-sujeito: experiências de pesquisa com alunos de escolas públicas. In: SOUSA, M. P. R. (org.). Ouvindo crianças na escola: abordagens qualitativas e desafios metodológicos para a psicologia. São Paulo: Casa do Psicólogo, 2010.

SCHWARTZMAN, J. S. (org.). Síndrome de Down. São Paulo: Mackenzie - Memnon, 1999.

SHAW, C.; BRADY, L.-M.; DAVEY, C. Guidelines for research with children and young people. London: National Children's Bureau, Research Centre, 2011.

SHUTTS, K.; BANAJI, M. R.; SPELKE, E. S. Social categories guide young children's preferences for novel objects. Developmental Science, v. 13, n. 4, p. 599-610, 2010.

SIGAUD, C. H. de S. et al. Aspectos éticos e estratégias para participação voluntária da criança em pesquisa. Revista da Escola de Enfermagem, v. 43, p. 1342-1346, especial 2, 2009.

SMITH, E.; NÆSS, K.-A. B.; JARROLD, C. Assessing pragmatic communication in children with Down syndrome. Journal of Communication Disorders, v. 68, p. 10-23, jul. 2017.

SOARES, N. F.; SARMENTO, M. J.; TOMÁS, C. Investigação da infância e crianças como investigadoras: metodologias participativas dos mundos sociais das crianças. Nuances: estudos sobre educação, v. 12, n. 13, p. 49-64, jan./dez. 2005. 
STOJANOVIK, V. Prosodic deficits in children with Down syndrome. Journal of Neurolinguistics, v. 24, n. 2, p. 145-155, mar. 2011.

TERRA, M. R. O Desenvolvimento Humano na Teoria de Piaget. Disponível em: https://www.unicamp.br/iel/site/alunos/publicacoes/textos/d00005.htm. Acesso em: 02 jun. 2020.

VAN DEN HEUVEL, E. et al. Atypical language characteristics and trajectories in children with $22 \mathrm{q} 11.2$ deletion syndrome. Journal of Communication Disorders, v. 75, p. 37-56, set. 2018.

VAN TILBORG, A. et al. Modeling individual variation in early literacy skills in kindergarten children with intellectual disabilities. Research in Developmental Disabilities, v. 72, p. 1-12, jan. 2018.

VÁSQUEZ, N. G. et al. Testing a method to assess the thermal sensation and preference of children in kindergartens. In: INTERNATIONAL PLEA CONFERENCE, 30., Ahmedabad, 2014. Proceedings [...] Ahmedabad, 2014.

VÁSQUEZ, N. G.; PEREIRA, F. O. R.; KUHNEN, A. Preferências visuais das crianças em salas de aula de educação infantil: uma aproximação experimental. Ambiente Construído, Porto Alegre, v. 18, n. 3, p. 1128, jul./set. 2018.

VOIVODIC, M. A. M. A. Inclusão escolar de crianças com Síndrome de Down. 7. ed. Petrópolis: Vozes, 2013.

WEINSTEIN C. S. et al. (ed.). Spaces for children. New York: Plenum Press, 1987.

ZAMANI, Z. Young children's preferences: what stimulates children's cognitive play in outdoor preschools? Journal of Early Childhood Research, v. 15, n. 3, p. 256-274, 2017.

\section{Acknowledgments}

All authors would like to thank the institutions, professionals, parents and children involved, for their trust. Sheila Walbe Ornstein and Gleice Azambuja Elali thank the National Council for Scientific and Technological Development $(\mathrm{CNPq})$ for partial funding through research productivity grants.

Virginia Magliano Queiroz

Departamento de Arquitetura | Faculdade Pitágoras | Rod. Jones dos Santos Neves, 1000, Lagoa Funda | Guarapari - ES - Brasil | CEP 29214-005 | Tel.: (27) 98126-3670 | E-mail: vimagliano@gmail.com

Sheila Walbe Ornstein

Departamento de Tecnologia da Arquitetura, Faculdade de Arquitetura e Urbanismo | Universidade de São Paulo | Rua do Lago 876, Cidade Universitária, Butantã | São Paulo - SP - Brasil | CEP 05508-080 | Tel.: (11) 97285-2875 | E-mail: sheilawo@usp.br

Gleice Azambuja Elali

Departamento de Arquitetura | Universidade Federal do Rio | Grande do Norte | Campus Central, Centro de Tecnologia | Natal - RN Brasil | CEP 59078-970 | Tel.: (84) 3215-3776 | E-mail: gleiceae@gmail.com

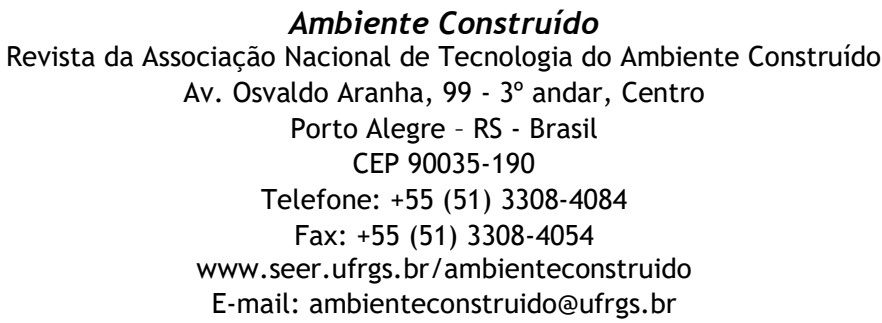

